\title{
KONSEP EKONOMI PADA MASA BANI UMAYYAH, ABBASIYAH DAN TURKI USMANI
}

(Devita Ayu Fildayanti/90100118020)

\section{Perekonomian Pada Masa Bani Umayyah}

Pada masa dinasti Bani Umayyah, khalifah Umar bin Abdul Azis berhasil menerapkan konsep welfare state yaitu negara yang sejahtera. Umar memiliki kebijakan baru untuk merubah taraf hidup masyarakat, salah satu buktinya yaitu tidak ditemukan seorang pun yang dapat menerima zakat karena seluruh masyarakatnya berkecukupan (Ghozali, 2019). Adapun kebijakannya adalah dalam pengelolaan dana jizyah, Umar menerapkan pengurangan beban jizyah atas pengikut agama kristen. Umar juga menerapkan kebijakan pengelolaan lahan mati, memberikan konsep penyuburan tanah hingga penanaman pohon, mendirikan bangunan, dan konsep kerjasama. Sedangkan runtuhnya Bani Umayyah berlangsung pada masa Abu Malik bin Marwan yang masih mempertahankan Gubernur Khurasan yaitu Nasr bin Sayyar. Kebijakan yang dikeluarkan yaitu menerapkan pajak kepada non muslim sehingga menimbulkan beberapa pemberontakan dan runtuhnya dinasti Bani Umayyah (Rizal, 2019).

Kemunduran dan kehancuran dinasti Umayyah juga disebabkan oleh faktor lain diantaranya perebutan kekuasaan antara keluarga kerajaan, konflik berkepanjangan, pertentangan etnis suku Arab Utara dan Selatan, ketidakcakapan khalifah dalam memimpin, kecenderungan hidup mewah, pergulingan oleh Bani Abbas yang didukung oleh Bani Hasyim, kaum syi'ah dan golongan Mawali (Zainudin, 2015). Jika dibandingkan dengan bidang keilmuan lainnya, sumbangan kekhalifahan Bani Umayyah di bidang ekonomi memang tidak begitu menonjol. Namun terdapat beberapa sumbangan pemikiran mereka terhadap kemajuan ekonomi islam, diantaranya adalah perbaikan konsep pelaksanaan transaksi saham, murabahah, muzara'ah serta kehadiran kitab AlKharaj yang ditulis oleh Abu Yusuf yang hidup pada masa pemerintahan khaifah Hasyim yang membahas tentang kebijakan ekonomi (Indasari, 2017).

\section{Konsep Ekonomi pada Masa Bani Abbasiyah}

Pemerintahan Daulah Abbasiyah merupakan kelanjutan dari pemerintahan Daulah Bani Umayyah yang telah runtuh di Damaskus. Dinasti ini berkuasa kurang lebih lima abad dan pusat pemerintahannya bertempat di kota Bagdad. Kemajuan di bidang ekonomi berimbas pada kemakmuran rakyat secara keseluruhan. Perkembangan bidang pertanian maju pesat pada awal pemerintahan Dinasti Abbasiyah karena pusat 
pemerintahannya berada di daerah yang sangat subur, di tepian sungai yang di kenal dengan nama Sawad. Pertanian merupakan sumber utama pemasukan negara dan pengolahan tanah hampir sepenuhnya dikerjakan oleh penduduk asli yang statusnya mengalami peningkatan pada masa rezim baru. Lahan-lahan pertanian yang terlantar dan desa-desa yang hancur diberbagai wilayah diperbaiki dan dibangun secara bertahap serta dibangunnya saluran irigasi baru. Puncak kemakmuran rakyat terjadi pada masa Harun alRasyid dan putranya al-Ma'mun. Kekayaan yang melimpah pada masa ini digunakan untuk kegiatan-kegiatan diberbagai bidang seperti sosial, pendidikan, kebudayaan, ilmu pengetahuan, kesehatan, kesustraan dan pengadaan fasilitas-fasilitas umum. Pada masa inilah berbagai bidang-bidang mencapai puncak keemasannya (Meriyati, 2018).

\section{Konsep Ekonomi pada Masa Turki Usmani}

Kerajaan Turki Usmani sebagai kerajaan yang mampu bertahan hingga abad ke20 yang lebih banyak difokuskan pada masalah kemiliteran dan perluasan wilayah. Dengan demikian kondisi ekonomi dan keuangan turut memberikan andil bagi perkembangan islam di kerajaan Turki Usmani. Terjadinya peperangan yang berkesinambungan yang menimpa Turki Usmani sangat menguras sumber dana. Peperangan yang terjadi berdampak pada merosotnya perekonomian karena pendapatan negara berkurang secara drastis sementara belanja negara semakin tinggi untuk biaya perang. Penguasa Turki Usmani tidak lagi memikirkan dan memperhatikan pola pembangunan dan rehabilitasi jalan-jalan, rumah sakit, sekolah-sekolah serta prasarana ekonomi seperti pembangunan sektor pertanian, pengairan atau pemeliharaan bendungan (Suar, 2020).

Turki Usmani mengalami masa kejayaan sejak permulaan sampai masa pemerintahan Sulaiman dan setelah Sulaiman, Usmaniyah mengalami kemunduran. Faktor utama kemunduran dan kehancuran Turki Usmani adalah buruknya pemahaman keislaman dan kesalahan dalam penerapannya. Selain itu, kegiatan ijtihad terhenti yang menyebabkan kebekuan berpikir, jumud dan stagnan sehingga pada saat Eropa mengalami kemajuan dengan berbagai penemuan sains dan industri, umat mengalami kebingungan untuk mengambil atau tidak yang berasal dari Barat. Tidak mampu membedakan antara ilmu dan tsaqofah, antara hadharah dan madaniah serta terjadinya konspirasi Barat bersama agennya Mustafa Kemal Attarturk yang menyebabkan keruntuhan Khilafah Islamiyah pada 3 Maret 1924 (Hasnahwati, 2020). 


\section{DAFTAR PUSTAKA}

Meriati. (2018). PERKEMBANGAN EKONOMI ISLAM PADA MASA DAULAH ABBASIYAH. Islamic banking. 4(1), 45-56.

Rizal, F. (2019). KEBIJAKAN EKONOMI PADA MASA KEKHALIFAHAN BANI UMAYYAH. Al-Tsaqafa: Jurnal Ilmiah Peradaban Islam. 16(2), 226-236.

Ghozali, M. (2019). KONSEP WELFARE STATE PADA KEBIJAKAN UMAR BIN ABDUL AZIZ SEBAGAI KHALIFAH BANI UMAYYAH. LAA MAISYR. 6(2), 282-296.

Indasari, D. (2017). PERKEMBANGAN PEMIKIRAN EKONOMI ISLAM PADA MASA BANI UMAYYAH. Jurnal Ilmu Pengetahuan Teknologi \& Seni. 9(2), 55-60.

Hasnahwati. (2020). PENDIDIKAN ISLAM DI MASA TURKI USMANI. Jurnal Andi Djemma | Jurnal Pendidikan. 3(2), 1-10.

Suar, A. (2020). PEMIKIRAN EKONOMI ISLAM PADA MASA AWAL TURKI UTSMANI. Al-Dzaha. 1(1), 53-71.

Zainudin, E. (2015). Perkembangan Islam pada Masa Bani Umayyah. Jurnal Intelegensia. 03(2), 28-35. 